\title{
Growth of Crotalaria juncea L. Supplied with Mineral Nitrogen
}

\author{
Elenira Henrique Miranda Mendonça and Marlene Aparecida Schiavinato ${ }^{*}$ \\ ${ }^{I}$ Departamento de Fisiologia Vegetal; Instituto de Biologia; Universidade Estadual de Campinas; \\ mschiavi@unicamp.br; C.P. 6109; 13083-970; Campinas - SP - Brazil
}

\begin{abstract}
Plants of Crotalaria juncea inoculated with Rhizobium were treated with nutrient solution containing 10 or $20 \mathrm{mg}$ of either $\mathrm{N} / \mathrm{NO}_{3}$ or $\mathrm{N} \mathrm{NH}_{4}$.plant ${ }^{-1}$. week ${ }^{-1}$. The control plants received nutrient solution without $\mathrm{N}$. An investigation was conducted on the effect of these sources of $N$ on growth and nitrogen fixation of plants with 30, 60 and 90 days after sowing (DAS). Those that received mineral $N$ presented higher growth than $-N$ plants, but the presence of nodules occurred in all the treatments. Plants treated with $\mathrm{NH}_{4}$ presented higher $\mathrm{N}$ content until 60 days. The highest concentrations of leghemoglobin and protein in nodules were found at 30 DAS and there was no difference in leghemoglobin content between treatments for any age and in protein from 60 DAS. Nitrogenase activity did not vary from 60 to 90 days, with the exception of plants that received 20mg $\mathrm{N}_{\mathrm{NO}}$, where it was higher at 60 days
\end{abstract}

Key words: Ammonium, nitrate, rhizobium, nitrogen fixation

\section{INTRODUCTION}

Nitrogen-fixing legumes have been used to maintain or increase crop yields and reduce production constraints in low-input agricultural systems. One of the means of achieving this is using "green manures" when a $\mathrm{N}_{2}$-fixing legume is grown either before, or with, a non-fixing crop in order to enrich the soil with $\mathrm{N}$ and hence reduce (or even eliminate) the need to apply $\mathrm{N}$ fertilizer to the non-fixing crop. C. juncea, a tropical legume, is able to obtain a substantial proportion of its $\mathrm{N}$ by symbiotic fixation with rizobia located in nodules (Dourado et al., 2001). These nodules provide a low oxygen environment for the optimum expression and operation of nitrogenase, the enzyme responsible for $\mathrm{N}_{2}$-fixation. They also provide an interface for the exchange of nutrients and metabolites between the symbionts (Dixon and Wheeler, 1986). The plant supplies photosynthetically-derived carbon to the bacteroids and, in return, the bacteroids pass fixed $\mathrm{N}$ (ammonium) to the host plant (Muller et al., 2001). The physiological responses of $C$. juncea plants to different forms of $\mathrm{N}$ such as ammonium and nitrate are very important in agriculture with regard to practical aspects of $\mathrm{N}$ application in intensive field production with fertilizers.

In the present study, the effects of ammonium and nitrate on growth, nodulation, and $\mathrm{N}_{2}$ fixation of C. juncea, inoculated with Rhizobium were analyzed.

\footnotetext{
Author for correspondence
} 


\section{MATERIALS AND METHODS}

\section{Plant material and growth conditions}

Plants of $C$. juncea were grown in a greenhouse under natural conditions, in $1.5 \mathrm{~L}$ pots $(1$ plant each) containing washed vermiculite and all of them were inoculated with a rhizobial strain isolated from Crotalaria retusa, tested in $C$. juncea for effectiveness (Mendonça et al., 1999). The plants were irrigated once a week with 100 $\mathrm{mL}$ of a balanced nutrient solution (Faria et al., 1988) containing different sources of mineral N. The experiment was arranged in randomized blocks with plants without N (BNF-biological N fixation only, as a control), 2 levels of $\mathrm{KNO}_{3}(10$ or $20 \mathrm{mg} \mathrm{N}$ plant $^{-1}$ week $\left.{ }^{-1}\right), 2$ levels of $\left(\mathrm{NH}_{4}\right)_{2} \mathrm{SO}_{4}$ (10 or $20 \mathrm{mg} \mathrm{N}$ plant $^{-1}$ week ${ }^{-1}$ ) with ten replicates for each treatment. An investigation was conducted on the effect of the sources of $\mathrm{N}$ on growth and $\mathrm{N}_{2}$ fixation of plants maintained for 30 , 60 and 90 days after sowing (DAS). The height, shoot (leaves + stem) and root dry mass, nodule fresh mass, total $\mathrm{N}$ in leaves, nitrogenase activity, protein and leghemoglobin (legHb) contents were determined.

\section{Total $\mathbf{N}$ in leaves}

All leaves, after drying at $65^{\circ} \mathrm{C}$, were digested with phenol-sulfuric acid using selenium as a catalyst for estimating total $\mathrm{N}$ using the Kjeldahl method (Nelson and Sommers, 1973).

\section{Nitrogenase activity}

Nitrogenase activity of root nodules was measured according to Hardy et al. (1968) by the acetylene reduction assay (ARA).

\section{Protein and leghemoglobin determination}

Nodules were weighed and then macerated in a chilled mortar with Drabkin's solution (Becana et al., 1986). The debris was centrifuged for $15 \mathrm{~min}$ $\left(4^{\circ} \mathrm{C}, 20000 \mathrm{~g}\right)$ and the supernatant was used for protein (Bradford, 1976) and leghemoglobin (Becana et al., 1986) determination.

\section{Statistical analyses}

Data were subjected to an analysis of variance, and when " $F$ " was significant, a comparison of means was carried out using Duncan's Multiple Range test at the $5 \%$ probability level.

\section{RESULTS AND DISCUSSION}

\section{Growth of $C$. juncea}

Dry mass production by plants grown on nitrate or ammonium was always higher than that of control plants, at all ages. The height and dry mass increment occurred mainly for the treatment with 20mg N.plant ${ }^{-1}$. week ${ }^{-1}$ (Fig. 1). It was interesting to observe that the control plants, at $90 \mathrm{DAS}$, did not present dry mass increase as observed in the other treatments, probably due to precocious senescence. Nitrogen deficiency has been shown to induce precocious senescence (Marschner, 1997). Therefore, leaf fall and root death might explain this data.

Both $\mathrm{N}$ sources were promptly utilized by $C$. juncea plants, since neither inhibition nor retarded growth effects were observed. This suggested that the utilization of the different $\mathrm{N}$ sources was equally efficient.

\section{Nodule fresh mass}

The presence of nodules was observed in all treatments, and plants that received ammonium or $10 \mathrm{mg}$ of $\mathrm{N} / \mathrm{NO}_{3}$ presented increasing levels of nodulation up to $90 \mathrm{DAS}$. N/NO $/ \mathrm{NO}_{3}$ at $20 \mathrm{mg}$ had no effect on nodule fresh mass, since values were similar to those of control plants, which were totally dependent on $\mathrm{N}_{2}$ fixation (Fig. 1D). These results confirmed positive effects of starter-N application on nodulation as described previously (Muller et al., 1993; Gonçalves et al., 1999).

\section{Total $\mathbf{N}$ in leaves}

The total organic $\mathrm{N}$ content in leaves of nitrate-fed plants was the same as for control plants from 30 to $60 \mathrm{DAS}$, although an increase was observed in plants that received ammonium, for the same period (Fig. 2A). After 60 DAS, there was a decrease in $\mathrm{N}$ content for all treatments. It is possible that the decrease at 90 DAS could be attributed to limited availability or to the remobilization of $\mathrm{N}$ for pod filling (Brown and Walsh, 1994).

\section{Protein and leghemoglobin content}

At the different ages the fresh mass of nodules increased continuously (Fig. 1D), but the protein (Fig. 2B) and legHb (Fig. 2C) concentration per fresh mass of nodules declined progressively. The highest concentrations of protein and legHb in nodules were observed at 30 DAS. There were no significant differences in legHb content between 
treatments for any age and in protein from 60 DAS. LegHb represented around $30 \%$ of the protein of alfalfa nodules (Becana et al., 1986), whereas the relative proportion of legHb/protein in nodules of $C$. juncea varied between treatments from 35 to $56 \%$.

\section{Nitrogenase activity}

$\mathrm{N}$-fertilizer has a well established negative effect on $\mathrm{N}_{2}$ fixation of some legume root nodules (Gibson and Harper, 1985). However, other reports showed that a synergistic effect could occur between $\mathrm{N}$-fertilization and $\mathrm{N}_{2}$ fixation, leading to an increase of plant growth (Yinbo et al., 1997). This synergism may be related to the $\mathrm{N}_{2}$ fixation efficiency of the rhizobial strain
(Santalla et al., 2001), to the concentration of $\mathrm{N}$ fertilizer (Hardarson, 1993) or to a suitable balance of soil nutrients (Tsai et al., 1993). In $C$. juncea plants, nitrogenase activity (ARA) did not vary from 60 to 90 days, with exception of plants that received $20 \mathrm{mg} \mathrm{N} / \mathrm{NO}_{3}$, when ARA was higher at 60 DAS (Fig. 2D). C. juncea showed greater tolerance to $20 \mathrm{mg} \mathrm{N} / \mathrm{NO}_{3}$ in the nutrient solution where nodulation was depressed, although nitrogen fixation per gram of fresh nodule increased. Numerically, the present assay showed a rapid decline of nitrogenase activity with time for the onset of pod-filling. The decrease was probably caused by the decrease of legHb content in the nodules (Mendonça, 1997).
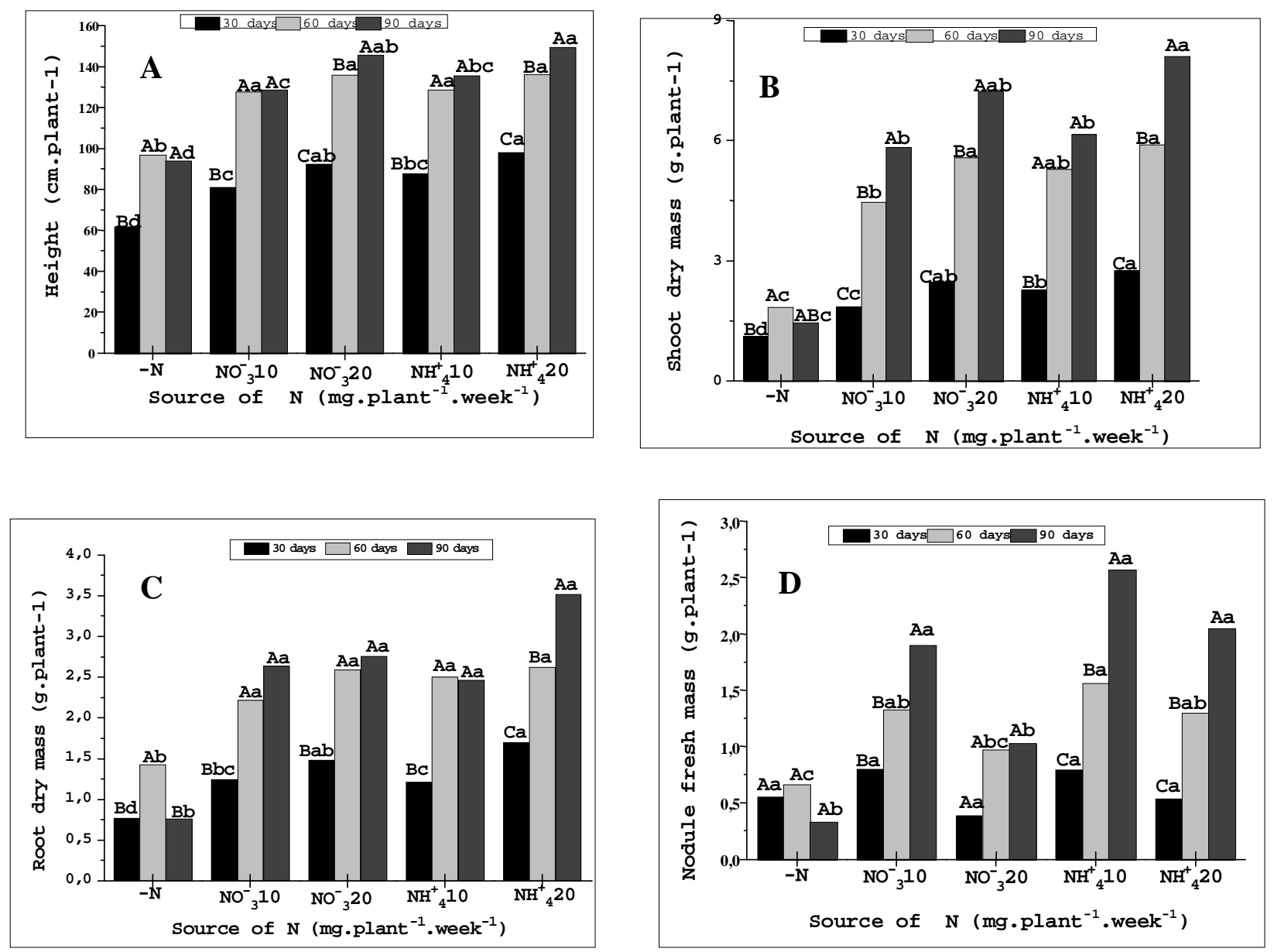

Figure 1 - Effect of mineral $\mathrm{N}$ on height (A), shoot (B), root dry mass (C) and nodule fresh mass (D) of Crotalaria juncea. Means with capital letters indicate differences among ages at same treatments, and minute letters indicate differences among treatments at same ages. 


\section{CONCLUSIONS}

We concluded that $C$. juncea might benefit from mineral $\mathrm{N}$ in interaction with effective Rhizobium strains, showing some synergistic effect between both $\mathrm{N}$ nutritional processes, leading to increased dry mass and nodulation. Mineral $\mathrm{N}$, at the concentration used, stimulated plant growth and did not inhibit the nodulation. The results obtained suggested that the application of starter mineral $\mathrm{N}$ in $C$. juncea culture could enhance biological $\mathrm{N}$ accumulation.
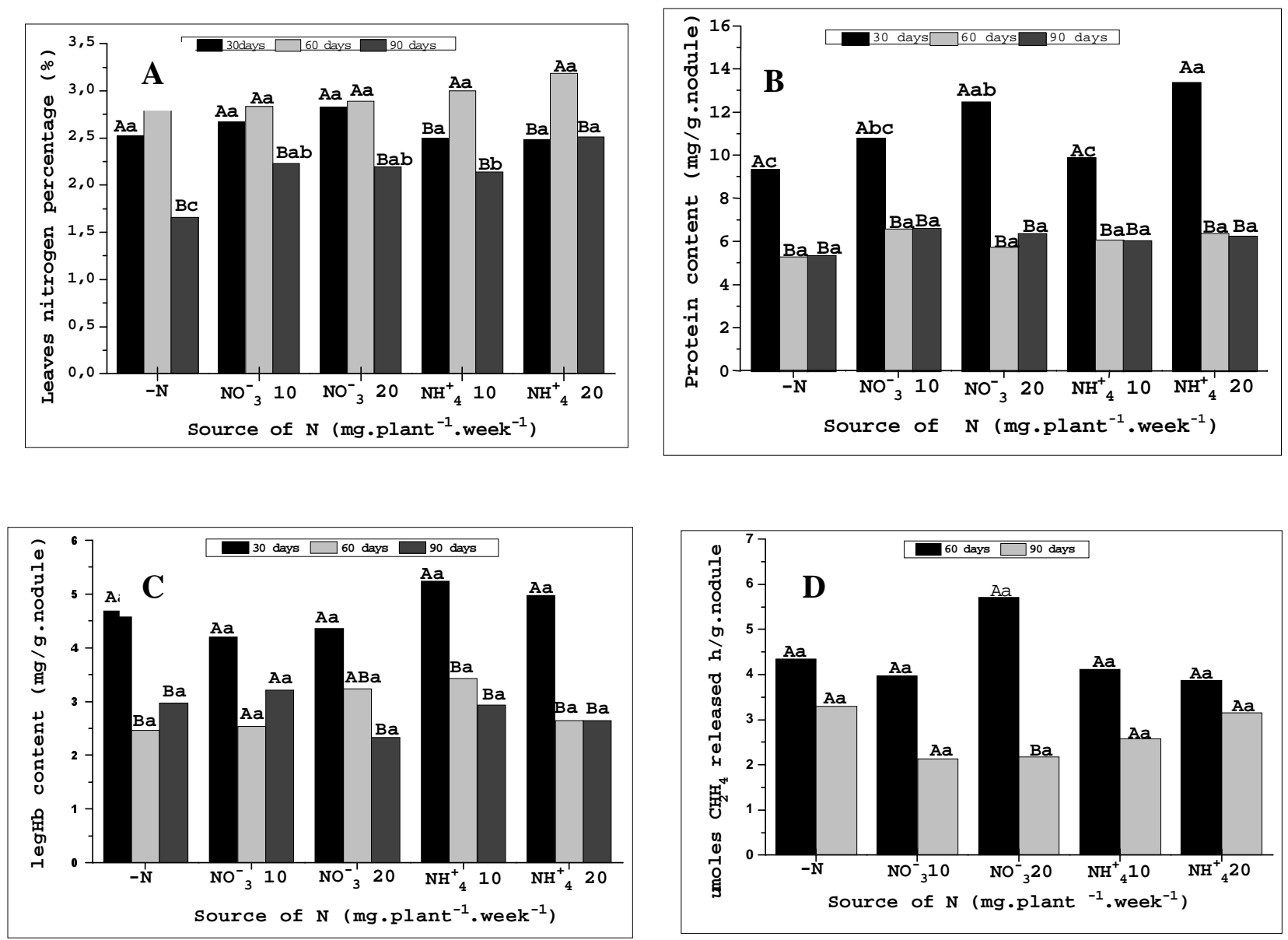

Figure 2 - Effect of mineral $\mathrm{N}$ on leaves $\mathrm{N}$ percentage (A), nodule protein (B), leghemoglobin content (C) and nitrogenase activity (D) of Crotalaria juncea. Means with capital letters indicate differences among ages at same treatments, and minute letters indicate differences among treatments at same ages.

\section{RESUMO}

Plantas de Crotalaria juncea inoculadas com Rhizobium foram tratadas com solução nutritiva contendo 10 ou $20 \mathrm{mg}$ de $\mathrm{N} / \mathrm{NO}_{3}$ ou N/NH 4 . planta $^{-1}$ .semana ${ }^{-1}$. As plantas controle receberam solução nutritiva sem N. Foi verificado o efeito destas fontes de $\mathrm{N}$ no crescimento e fixação de nitrogênio em plantas com 30, 60 e 90 dias após a semeadura
(DAS). Aquelas que receberam $\mathrm{N}$ mineral apresentaram maior crescimento que plantas $-\mathrm{N}$, mas a presença de nódulos ocorreu em todos os tratamentos. Plantas tratadas com $\mathrm{NH}_{4}$ apresentaram maior conteúdo de $\mathrm{N}$ até os 60 dias. As maiores concentrações de leghemoglobina e proteínas em nódulos foram verificadas aos 30 DAS e não houve diferença no conteúdo de leghemoglobina entre os tratamentos, em nenhuma 
das idades e em proteínas a partir de 60 DAS. A atividade da nitrogenase não variou dos 60 aos 90 dias, com exceção de plantas que receberam $20 \mathrm{mg}$ $\mathrm{N} / \mathrm{NO}_{3}$, nas quais esta foi maior aos 60 dias.

\section{ACKNOWLEDGEMENTS}

E.H.M. Mendonça thanks CAPES-Brazil for the fellowship.

\section{REFERENCES}

Becana, M.; Gorgocena, Y.; Aparicio-Tejo, P. M. and Sánchez-Días, M. (1986), Nitrogen fixation and leghemoglobin content during vegetative growth of Alfalfa. J. Plant Phyiol., 123, 117-125.

Bradford, M. M. (1976), A rapid and sensitive method for the quantitation of microgram quantities of protein utilizing the principle of protein-dye binding. Anal. Biochem., 72, 248-254.

Brown, S. M. and Walsh, K. B. (1994), Anatomy of the legume nodule cortex with respect to nodule permeability. Australian J. Plant Physiol., 21, 49-68.

Dixon, R. O. D. and Wheeler, C. T. (1986), Nitrogen fixation in plants. Glasgow : Backfield. $157 \mathrm{pp}$.

Dourado, M. C.; Silva, T. R. B. and Bolonhezi, A. C. (2001), Matéria seca e produção de grãos de Crotalaria juncea $\mathrm{L}$. submetida à poda e adubação fosfatada. Sci. Agric., 58, 287-293.

Faria, S. M.; Hay, G. T. and Sprent, J. I. (1988), Entry of rhizobia into roots as Mimosa scabrela Benthan occurs between epidermal cells. J. Gen. Microbiol., 134, 2291-2296.

Gibson, A. H. and Harper, J. E. (1985), Nitrate effect on nodulation of soybean by Bradyrhizobium japonicum. Crop. Sci., 25, 497-501.

Gonçalves, C. A.; Goi, S. R. and Jacob-Neto, J. (1999), Crescimento e nodulação de Inga marginata em resposta à adição de nitrogênio, fósforo e inoculação com rizóbio. Floresta e Ambiente, 6, 118-126.

Hardarson, G. (1993), Methods for enhancing symbiotic nitrogen fixation. Plant and Soil, 152, 1-17.

Hardy, R. W. F.; Holsten, R. D.; Jackson, E. K. and Burns, R. C. (1968), The acetylene- ethylene assay for $\mathrm{N}_{2}$ fixation: laboratory and field evaluation. Plant Physiol., 43, 1185-1207.
Marschner, H. (1997), Mineral nutrition of higher plants. San Diego : Academic Press. 889 pp.

Mendonça, E. H. M. (1997), Fixação de $\mathrm{N}_{2} \mathrm{em}$ Crotalaria juncea L.: efeito de $\mathrm{NO}^{3}$ e $\mathrm{NH}_{4}$. MSc Thesis, Unicamp, Campinas, SP, Brazil.

Mendonça, E. H. M.; Mazzafera, P. and Schiavinato, M. A. (1999), Purification of leghemoglobin from nodules of Crotalaria infected with Rhizobium. Phytochemistry, 50, 313-316.

Muller, J.; Boller, T. and Wiemken, A. (2001), Trehalose becomes the most abundant non-structural carbohydrate during senescence of soybean nodules. J. Exp. Bot., 52, 943-947.

Muller, S. H.; Pereira, P. A. A. and Martin, P. (1993), Effect of different levels of mineral nitrogen on nodulation and $\mathrm{N}_{2}$ fixation of two cultivars of common bean (Phaseolus vulgaris L.). Plant and Soil, 152, 139-143.

Nelson, D. W. and Sommers, L. E. (1973), Determination of the total nitrogen in plant material. Agron. J., 65,109-112.

Santalla, M.; Amurrio, J. M. and Ron, A. M. (2001), Symbiotic interactions between Rhizobium leguminosarum strains and Elite cultivars of Pisum sativum L. J. Agron. and Crop Sci., 187, 59-68.

Tsai, S. M.; Bonetti, R.; Agbala, S. M. and Rossetto, R. (1993), Minimizing the effect of mineral nitrogen on biological nitrogen fixation in common bean by increasing nutrient levels. Plant and Soil, 152, 131-138.

Yinbo, G.; Peoples, M. B. and Rerkasem, B. (1997), The effect of $\mathrm{N}$ fertilizer strategy on $\mathrm{N}_{2}$ fixation, growth and yield of vegetable soybean. Field Crops Res., 51, 221-229.

Received: May 21, 2003; Revised: January 27, 2004; Accepted: September 09, 2004. 